Témoigner Témoigner. Entre histoire et mémoire

Getuigen Revue pluridisciplinaire de la Fondation Auschwitz

$118 \mid 2014$

Au nom des victimes. Dictature et terreur d'État en Argentine, Chili et Uruguay

\title{
The Jewish Museum and Tolerance Centre in
}

\section{Moscow}

Le musée juif et le centre pour la tolérance de Moscou

Het Joodse Museum en Centrum voor Tolerantie in Moskou

\section{Ewa Bérard}

\section{(2) OpenEdition Journals}

\section{Electronic version}

URL: http://journals.openedition.org/temoigner/1226

DOI: 10.4000/temoigner.1226

ISSN: 2506-6390

\section{Publisher:}

Éditions du Centre d'études et de documentation Mémoire d'Auschwitz, Éditions Kimé

\section{Printed version}

Date of publication: 1 October 2014

Number of pages: $12-15$

ISBN: 978-2-84174-674-3

ISSN: 2031-4183

\section{Electronic reference}

Ewa Bérard, «The Jewish Museum and Tolerance Centre in Moscow», Témoigner. Entre histoire et mémoire [Online], 118 | 2014, Online since 01 October 2015, connection on 23 October 2020. URL http://journals.openedition.org/temoigner/1226 ; DOI : https://doi.org/10.4000/temoigner.1226 


\section{THE JEWISH MUSEUM

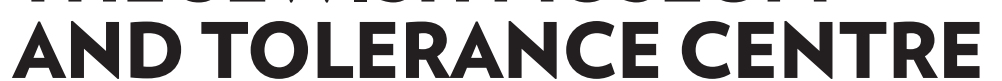 IN MOSCOW}

VISIT Created at the initiative of Dov-Ber-Pinhos Berez Lazar, Chief Rabbi of Russia since 1999, the Jewish Museum in Moscow opened its doors in November 2012. The inauguration took place in the presence of the president of Israel, Shimon Peres, and the Minister of Foreign Affairs of Russia, Sergei Lavrov.

$\mathrm{T}$ Museum was established through private funding, subsidies from the Russian government and from the Federation of th Jewish communities of Russia, an inheritor habad, an ancient Hasidic novenent hat prospered Putin gave one month of his salary to the funds of the Putin gave on

Whilst Moscow is disfigured by turgid and monumental constructions, the building of the Museum ( former bus depot on the Bakhmetev street) protecte its silhouette. Concen Madinir Shukhovin 1926-1927, this jewelof Construc. hood Marina Rochtcha, was placed, in 1997 , on the lis of monuments to be privatized and given by the town was the olim was the oligarch Roman Abras butch. It was indeed very close to being disfigured, but the intervention of public and professional opinions allowed the damage

The exhibition space is organized according to a circular plan. A centre with a double core is surrounded by walls forming two concentric circles: the "great Jewish cosmos" - cradle of Judaism, ancient Hebrews Shtetl Upon the wall that surrounds themos - the ted photos illustrating the "living Judaism", it rites ted photos illustrating the living Judaism", its rites the centre, creates with the first wall a hallway where the cene, each reserved to a different historical period. Parapets fixed on both sides of the wall provide more detailed nformation.

The Museum's ambition is to go beyond the tradiional "museum" aspect and to arouse interest in its technological performance, "unique in Russia", we are told. It aims to be a place of distraction, capable of attracting young people. The conception of the design was therefore trusted to Ralf Appelbaum's American agency, known for its realization of the Holocaust Museum in Washington. Visitors only encounter screens during the tour: big, small, medium-sized, flat, curved, at times interactive, at other times in 3D, accompanied by written or audio legends. Artefacts are relegated to the space dedicated to temporary exhibitions, at the periphery of the three circles. What makes this universe of screens completely surrealist, are the poet Iossif Brodski's words, engraved above... the Museum boutique: "The objects that we produce with our hands say more about us than our confessions." "p "products made with our hands" here. Craft worker and people of the Book are no longer. They have been "The a virtual people.

The "shtetl" space is in this regard exemplary Indeed, visitors are here invited to dress up in virtual floating in rewl barrels, to recognize their ancestors loating in real baress, to recognize their ancestors among plaster figures, like the one who is sat on book their head covered with the Tallit (inexplicably forothen, this old Jew in plaster is not interactive and does not swing from side to side). The best find without contest, is the virtual scroll of the Torah that unfolds at the desired speed from nic stick.

How was the history of the Jews in the empire (1775-1917), then in the USSR (1918-191)-1917), the In the USSR (1918-199) conceived? It was ion of this tortuos past, and also, sion or this to tus past, and also, to respect the ideological inperatives. The or the Centre, Nathalie Fichm, was clear. Indeed, the Museum's vocatov was not to bear withess to "the Sovis anti-Senitisn" (sic): "We will not shed tears for ourselves. It is not about exposing our offences, it is cout showng how we lived, how our country's history shaped us and how
we shaped its history." The tim listory.

The timeline leads to a map of the

"zone of residence" and the Kingdom

of Poland (although at the time of the census, it was only called the "Vistula Country"), which shows the percentage of Jews anong the population and the the $18^{\text {th }}$ century is very clear on the Polish origin the 18 century is very clear on the Polish origin of in Poland, and on their culture inherted from the

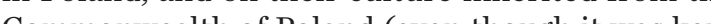
Con quiet that Polish Jews enjoyed the security of peop

The and beyond. 1795-1913" opens onto a large photo of an urban artery, a slightly surprising symbol of life as a Jew in the 19 century, yet

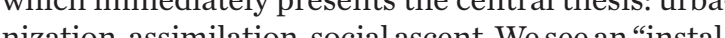

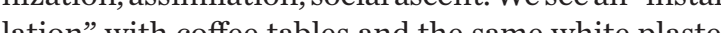

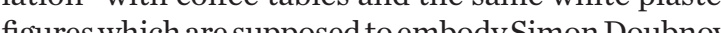
Sho wiches urban Jewi. "Ch curo urban J" events" proposes themes such as Haskalah (Jewish pogro, Jew ish press, ciltion, pogrns, ence much infor hou The Protocols of the Elders of Zion, could have foun, The Protocols of the Elders of Zion, could have

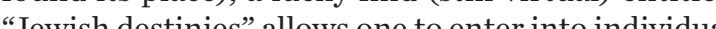

\section{Inside the museum.}

time and to follow, with headphones and a small screen he biographies of remarkable men.

The following tion, 1914-1921,1921-1941". On the bigscreen the doci, 19 German army, the scene of the revolutions of February

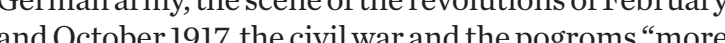
cruel than the pogroms of Khmelnitsky" (bus "nore cruel than the pogroms of Khmelnitsky" (but the proprojected Di-Sennitistions ore raised the "zone projected." iffult questions a rased: the "zone of They owe everything to the revolution, and the sterts They owe everything to the revolution, and the stereofrom the revalution, clever to quickly rise up to the from the revolution, clever to quickly rise up to the orening froms of terror. On the screen, the voice of a specialist of pow the Bunticexplains that with the seizure the difficult disma to adapt or to dis faced". We the dificult dilemna: to adapt or to disappear". We we USS $\mathrm{In}$ the was offere the

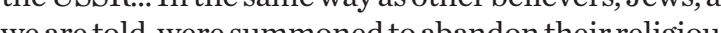
we are told, were summoned to abandon their religious practices though, thanks to their level of higher educawithin the new intellectual and professiontelite. 
We begin to grasp the function of the big screen which each section is equipped with: it must, whateve the cost, inscribe Jewish history within Russian gene-

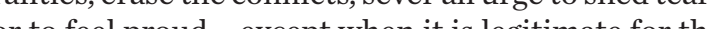
or to fed proud - except when it is legithate for the greatpopleof the Us aive pointed star embodies this young Soviet nation, f Jewis re the visitor, we can press it and the personality's short he visitor, we can $\mathrm{p}$ biography appears.

We approach the room dedicated to the Great atriotic War, 1941-1945: the most vast of all rooms plunged in darkness, with a screen that allows severa rojections simultaneously. Images of the Wehrmacht' densive on the western territories of the USSR, abandoned by the Soviet army, are projected; the reasons of

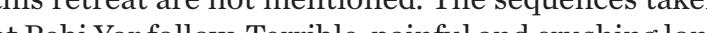
thabi Yar follow. Terible, painful and crushing long mo the glory of the victors, denens, and the glory or the victors, songs, and once again scenes f Berlin. The soldiers traverse the bu in direction Berin. The soldiers traverse the burnt villages of

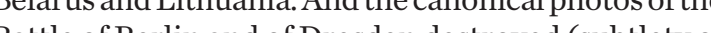
Batlo lowing the victory: we return to the scinn Yar mass victory: where hundreds of thous of Yere right to the Kaddish nor even to were not given the right to the Kaddish nor even to tive plaque. We seek in vain the reasons for this ne tive plaque. We seck in vain the reasons for this new is missing from this ribbon of images of course yes, is Stain. Trom this ribbon of inages. of course, yes, is Stalin. The great Stalin only appeared on screen fo a second, presiding the parade of 8 November 1941 on Soviet seople to victory, who saved the lives of millio Soviet people to victory, who saved the lives of million hid them over to the Gestapos (when he did not hand them over to the Gestapo or did not It is nout It is not about smoothing over the rough edges anyfrom the vilory in Stalingrad, thecame the starting from the victory in Stalingrad, became the organize of the State's anti-Senitism and of the chauvinistic Russian propaganda.

With Stalin absent, the Museum is not in a posiJewish experience of the war: the novel Life and Fate

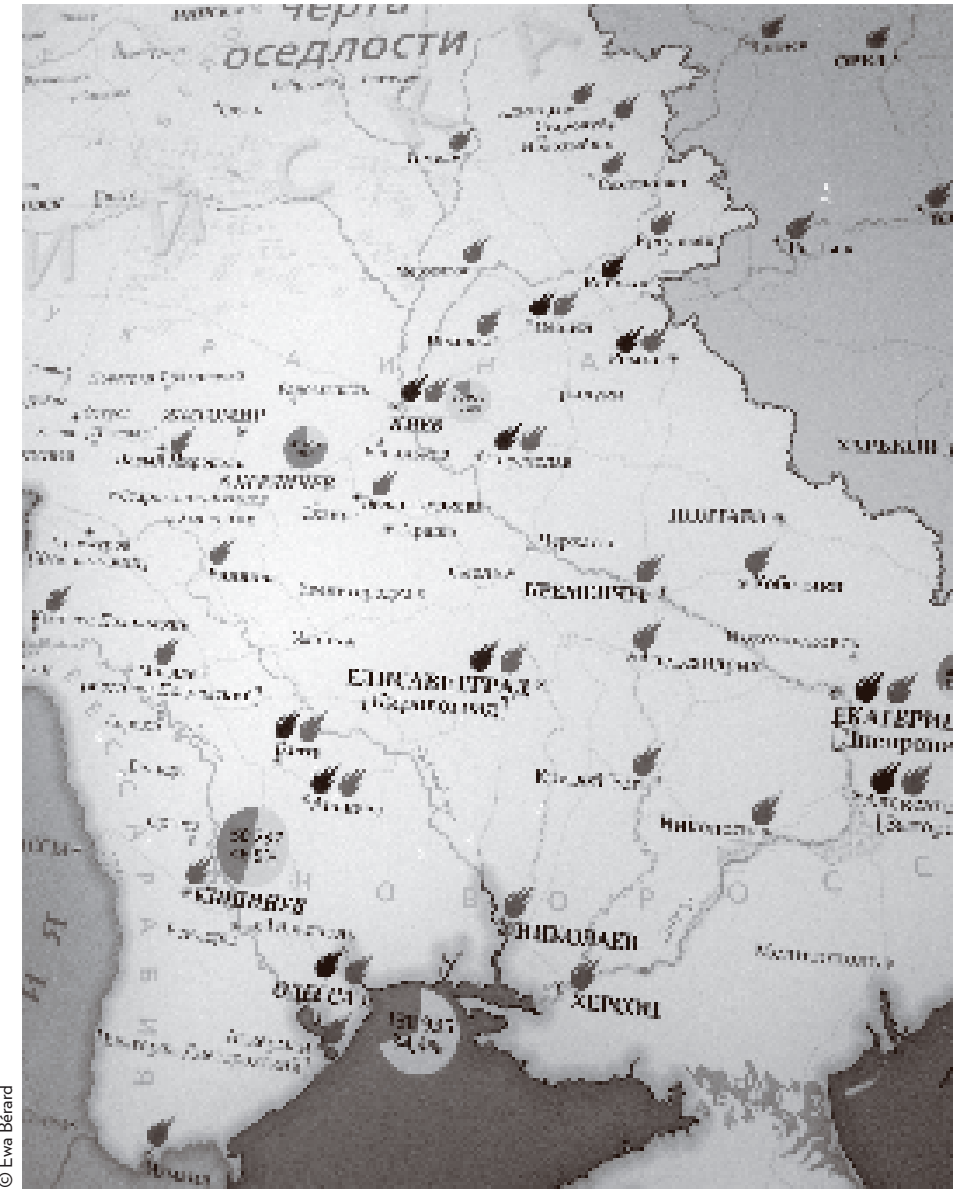

- Map of the pogroms at the beginning of the among the population and the intensity of the pogroms.

by Vassili Grossman. The interests of both parties of the Museum worked together in this avoidance strategy: Putin's doxa, that in advance excludes everything that may uphold the image of the Great Patriotic War, a fortiori a comparison of Stalin and Hitler's regimes (the main lines of Grossman's novel), and Habad, who has no reason to honour the culture of secular Soviet Jis, having become communists.

Disconcerted by this truncated history, we turn toward the explanatory panels. Yes, the Molotov-Ribbentrop Pact is mentioned, as well as the consequences tos and of Jews. Yes, here is mention of the ghet occupier. The Jewish Anti-Fascist Committee (JAC) created in 1942, is present yet without mentioning it Stalin, of its two initiators, Henryk Erlich and Victor Adler, Polish Jews. The visitors famous Black Book with the names of both ant fanous Black Book with the names of both authors, Finstein in the instein, in the niters and scientists, who Jew the JAC to publish a book on the wo the Jew the JhC to publish a book on the fate of the Jews occupied countries) and its end will remain unknown. Tho "denied publicatio" This is a euphenich Book was "donied publication. This is a euphemism: the leads, as well as all the printing equipment of the Der The of

The post-war pent the of in the 1930s. is conf to a in the 1930s, is confined to a small room without any aun 1950s". In Russian historiography this expressio traditionaly pertains to the power vacus expression century, when the country was still subjected to 17 cers and foreign armies. By dint of silenct the narpefs ande, the historical vision, ni ving of the Guide, th

On the back wall - in small dimensions - a photo of the underground cells of the Lubyanka Building. Five pillars each equipped with a screen present to the visitors in a disorderly sequence: (1) a photo of Andrei Jdanov, with a caption on his famous report dating from August 1946 which launched the "campaign against cosmopolitans"; (2) the photos of the photon photousolon a caption on his assassination in January 1948 and the

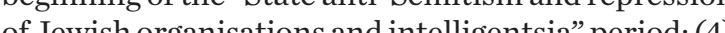
of Jewishorganisations and intelligentsia" period; (4) in May 1947, with the support of A the Israeli State in May 1947, with the support of Andrei Gromyko, at the "feling of pride" this event "awoke in the talks the "feelingor pride" this event "awoke in the hearts of many Soviet Jews", but is very areful not to compare (5) the headline of a new (5) the headline of a newspaper - anonymous! - that On the five pillars Stalin's name on white coats". On these five pillars, Stalin's name only appears once.
His photo, never.
As we progress further toward the present day, the past is redo anecdotes. To talk about the Sovie the on the State repression and anti-Semitism. The two screens. The firstone in $3 \mathrm{D}$ presents are only partment where two young peope are exchanging Jewish jokes on their own people as a young wom lifts from a On the second On the second it the in a forest seneration grows up, healthy in body and in mioung The visit is finished or just about There is still

The visit is finished - or just about. There is still
"Tolerance Centre" I the "Tolerance Centre". I am explained that its actiduring the the during these tims? Do questions about the current the toward people with "sexul ori such as the attiof the norm" or A to be raised? The person responsible for the Ceom to be raised. The person responsible for the Centre tution Shocked, sheoffers me two bro hures. We that the works sho ore designed for They fulfil the criteria det by the State's education. chey fulfil the criteria set by the State's educationa programs. Among the goals to be reached "on a peronal level lies: "Motivation and orientation of the cociety and of the State. Motivation and orientation of the values, founded upon the ideas of patriotism love and respect for the Hom the ideas of patriotism, tion of rect rights of nations and the partic recogndifferent cultures" So is it here, within this edurity of "tolenanc" which is in fact mely the co dition to the State's wiacin will find the rey to understand this astounding that we of the history of Soviet Jews? A version which seems to have gained Muscovites'support for many heems to have gained Muscovites support, for many have returof the high-tech gadgets, the same intellectuals who denounce, indignant, the return of Soviet practic within he, indignant, the return of Soviet practices all form of critical reflection.

Ewa Bérard, October 2013

The full (French) yersion of this text will be published
in the Revue des Etudes slaves. 